\title{
Factors that influence Malay students in purchasing skincare products in Malaysia
}

\author{
Nazatul Shima Abdul Rani \\ K. Sarojani Devi Krishnan \\ Universiti Kuala Lumpur, Business School \\ Kuala Lumpur, Malaysia
}

Keywords

HALAL, brand, safety, quality, price, Malay

\begin{abstract}
Skincare products have had a huge impact on the skin of users either positively or negatively. Most people are becoming more concerned about the harmful effects of chemicals used in skincare products. In Malaysia, most of the users are Malays who are generally Muslims. As Muslims, they use Halal products that are free of porcine or animal substances that are not being processed according to Islamic principles. Hence, this study aims to explore the main factors which are taken into consideration when Malay students purchase skincare products. A total of 100 questionnaires were distributed to Malay students in Kuala Lumpur, Malaysia to gain feedback on the factors that influenced them to buy skincare products. The findings show that most Malay students considered Halal, product safety, brand, price and quality as being the most important factors when purchasing skincare products. This paper highlights that most Malay university students in Malaysia preferred to purchase skincare products that are Halal, safe, of high quality and reputable brands. They were even willing to pay more for high quality skincare products that fulfil the above criteria. Thus, the findings of this study have an implication on appropriate marketing strategies to be implemented for future skincare products to boost sales and profits in the Malaysian market.
\end{abstract}

Corresponding author: Nazatul Shima Abdul Rani

Email addresses for corresponding author: shima.rani@unikl.edu.my

First submission received: $5^{\text {th }}$ December 2017

Revised submission received: $8^{\text {th }}$ February 2018

Accepted: $16^{\text {th }}$ March 2018

\subsection{Introduction}

Cosmetics-related business in Malaysia is growing rapidly and gaining much attention among industry players (Hashim and Musa, 2014). As reported by Hassali Al-Tamimi, Dawood, Verma and Saleem, (2015), Malaysian consumers spent around US407 million on cosmetics and toiletry products alone in 2013. In fact, skincare products are one of the main key drivers of the cosmetics markets that is worth US\$229 million. Although, skincare products are gaining much demand in Malaysia, several studies show that most cosmetic users are exposed to dangerous side effects caused by skincare or cosmetic products, yet they are still using these products to satisfy their egoistic needs (Ayenimo, Yusuf, Adekunle, \& Makinde, 2010; Mansor, Ali \& Yaacob, 2010). Generally, users assume that skincare products are safer and pose no risks to human health. In fact, some consumers do not read the labels for useful information to identify the ingredients contained in the cosmetic products before they decide to use them; they are not very concerned about the implications of using cosmetics especially to their health and body (Mansor, Ali \& Yaacob, 2010; Amasa, Santiago, Mekonen, \& Ambelu, 2012; Ayenimo et al., 2010). Since most of the Malaysian population comprise Malays who are mostly Muslims, the demand for halal skincare products are gaining much attention. Several studies have been conducted by other researchers on marketing of these products (Kaur \& Mutty, 2016), halal cosmetics (Hashim \& Musa, 2014; Musa, 2014), and halal brands (Kordnaeij, Askaripoor, \& Bakhshizadeh, 2013). The purpose of this research is to explore the most important factors considered by Malay university students when purchasing skincare products in Malaysia. The findings of the study will have implications for manufacturers and marketers before they market Halal skincare products in Malaysia. 


\subsection{Literature Review}

\subsection{Skin care Products}

Skincare is defined as the method one uses to keep his or her skin in the best condition, and skin care products are defined as all products used for cleansing, massaging, moisturizing, and others for face and hands (Khan \& Khan, 2013). Skin care products include cleansers, facial masks, toners, moisturizers, tanning salts and lotion, skin lighteners, serums, sunscreen and exfoliating products (Khan \& Khan, 2013).

\subsection{Main Factors influencing the Purchase of Skin Care Products}

Due to lack of research focusing on the preference to purchase skin care products by the Muslim Malay community in Malaysia, this study investigated factors that were considered essential in purchasing skin care products among them. Since the number of millennia or generation $\mathrm{Y}$ is increasing and most of them are studying in institutions of higher learning, thus this study focused on Malaysian university students' behaviour in purchasing skin care products. This group of market segment will be the future targeted market. The factors that were identified included Halal status of products, brand, safety, price, and quality.

\subsubsection{Halal}

Generally, Halal for Muslims is defined as a living concept centred on cleanliness, integrity, and self-restrain (Khattak, 2009; Kaur and Mutty, 2016). Cosmetics and personal care products must comply with the Malaysian Standard MS 2200:2008 requirements of halal certification. In producing goods and services, a person must uphold 'halalan thoyibban' which is a practice to comply with the quality standards, safety, and wholesomeness as required in Islam (Man, Bojei, Abdullah, \& Latif, 2007). In fact, Halal cosmetics can be defined as sources of ingredients of halal cosmetic products that include halal animals (land and aquatic), plants, microorganism, alcohol, chemicals, soil, and water as long as they are not hazardous and najs according to the Malaysian Standard, MS2200 (2008).

Halal certification is regarded as an official recognition that a product is manufactured in compliance with the principles of the Islamic Shariah law (reuters.com, 2016). Halal products including cosmetic products have the potential of being offered not only to Muslims, but to the world at large (Khattak, 2009). Jabatan Kemajuan Islam Malaysia (JAKIM) is an important body for regulating and certification of halal products including cosmetics and customers are advised to look for the halal logo which affirms that the product is halal before purchase. According to Hunter (2012), halal awareness has become widespread and this started with the concern on meat-based products a decade ago to a wide range of products today. Muslim consumers are now seeking for Halal trustworthiness of processed foods, beverages, pharmaceuticals, insurance, travel, leather products, and even entertainment. Although commonly associated with food and beverages, halal in fact applies to all aspects of life for practitioners of Islam, including items such as pharmaceuticals, personal care, skincare, and hair care products. In conclusion, the term "halal" in skincare products means the product must be free from food of animal origin such as pigs and dogs. It also includes food of plant origin that contains intoxicating and hazardous elements present in the product which are also prohibited (Ali, Halim, \& Ahmad, 2016). As such hypothesis 1 is proposed:

H1: Malay students prefer HALAL skin care products.

\subsubsection{Brand}

The customer is also influenced by the branding of the product when it comes to skincare. They tend to buy products that are well-known while following the trend or popularity of the products without referring to health experts. Businesses that embrace their brands fully are the ones that people will remember (Foster, Haltiwanger, \& Syverson, 2016). Hence, to build a successful brand, businesses need to have strong marketing strategies. About $75 \%$ of Americans think that companies whose brands are popular should implement better strategies in order to encourage brand loyalty (Foster, Haltiwanger, \& Syverson, 2016). Despite this, most advertisements related to a brand, most often than not attempt to build a strong image of the brand by getting across the fact that the brand can be trusted, and customers can rely on them. Thus, branding can turn a commodity into something more valuable by fostering preference and loyalty, leading to repeat purchases and often increased profit margins. As such hypothesis 2 is proposed: 
H2: Malay students prefer branded skin care products.

\subsubsection{Product Safety}

When it comes to purity and cleanliness of the product, customers must be careful about the originality and safety of the skin care products they use. Most chemicals are added to cosmetic products in the form of preservatives and fragrances that might be toxic and might cause cancer, mutation, reproductive toxicity, and endocrine disruption (Amasa et al., 2012). Heavy metals are also incorporated into beauty products for many purposes. In a study that was conducted by Ayenimo, et al., (2010), they stated that the toxicity of heavy metals is well-documented and can cause damage to the internal body organs of animals and humans. Other than that, the perception of some skin care users is that brands and quality of skincare products make them ignorant of the ingredients contained in the products that might not be safe for them to use and this is becoming a major issue (Mansor, Ali, \& Yaacob, 2010). According to the New Strait Times (May 2017), the Health Ministry's National Pharmaceutical Regulatory Department (NPRA) has named seven cosmetic products that contain scheduled poison which can be harmful to health. These cosmetics if absorbed by the body can cause damage to the kidney and nervous system. It can also affect the development of a child's brain. Cosmetic products must not contain any ingredients listed as banned substances or substances used beyond its allowable conditions such as restricted concentrations and uses.

Information on banning ingredients with specific conditions of uses and concentrations are available in the Guidelines for Control of Cosmetic Products in Malaysia (National Pharmaceutical Regulatory Agency Ministry of Health Malaysia). All notified products marketed in Malaysia must be manufactured in a premise that conforms to the requirements of Good Practice in Malaysia. Thus, safety of skincare products requires that the products conform to health and safety standards to reduce health hazards they may cause to consumers. These hazards may not occur during short term but may have long term effects after continuous use of the products. As such, hypothesis 3 is proposed:

H3: Malay students prefer safe skin care products.

\subsubsection{Price}

Consumers have always wanted the right price for every purchase of products and services. If the price set does not reflect the value of a product, the customer may not be satisfied. Pricing is important because it leads to goods or services used by or rendered to consumers. Prices are often associated with quality (Kotler \& Keller, 2009). According to Alfred (2013), no matter what type of product it may be, some people will not pay more than a particular price, while others may purchase it. A product must reach the desired level of performance to attract people to purchase it. Certain types of products with high prices are regarded as of high quality and vice versa. As stated by Ralston (2003), perception is important as an external factor and is a form of available information for customers during decision making before a product is purchased. In conclusion, price is used as an indicator of product quality; if a product exceeds expectations it will lead to higher satisfaction (Alfred, 2013, Kotler \& Keller, 2009; Ralston, 2003). As such, hypothesis 4 is proposed:

H4: Malay students prefer expensive skin care products.

\subsubsection{Product Quality}

According to Kharim (2011), product quality includes features and characteristics of a product or service with the ability to satisfy stated or implied expectations of the consumer. Product quality can be defined as the degree of how well the product specification meets or exceeds the customer's expectation (Thomas \& Alex, 2011). According to Khan and Noor (2012), quality is the realization of the consumer's needs. Thus, quality is a continuous process to make and retain satisfaction of needs, both affirmed and required. Quality assurance plays an important role in skincare products. Quality assurance is a guaranteed offer by the product or service provider to meet a certain quality level. All notified cosmetic products must comply with the requirements stipulated in the Guidelines for Control of Cosmetic Products in Malaysia. As stated in the guidelines the product has to be ensured that it is safe for use and of good quality. Cosmetic products must not contain any ingredients listed as banned substances or substances used beyond its allowable conditions such as restricted concentrations and uses. As such, hypothesis 5 is proposed: 
H5: Malay students prefer high quality skin care products.

The conceptual framework for this study is shown in Figure 1 below.

Independent Variable

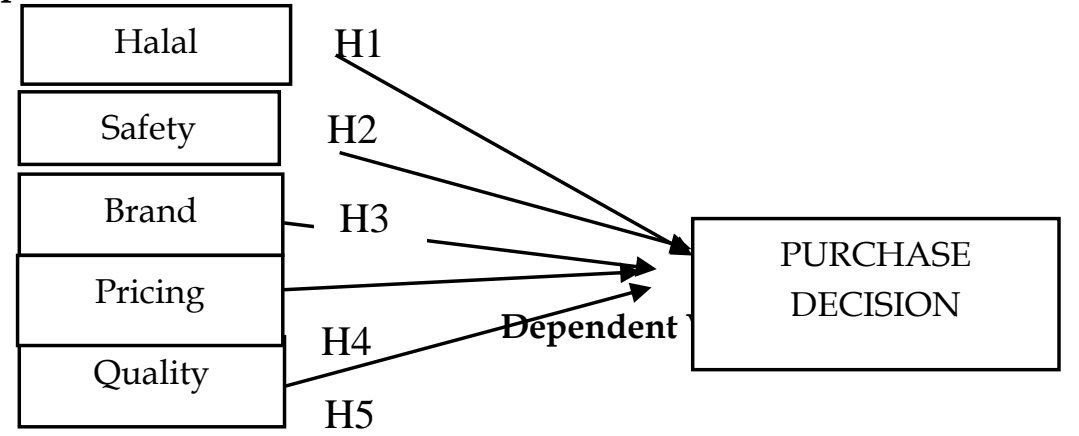

\subsection{Methodology}

Figure 1: Conceptual Framework

\subsection{Scope of study}

Our research focused on Malay students aged 18 and above, including both male and female students. The population of the study was categorized into three main age groups: from 18 to 20,21 to 23 , 24 years old and above. The target sample for this study consisted of Malay students around Kuala Lumpur or Klang Valley, and for this study, 100 students were chosen randomly.

\subsection{Population and Sample Size}

According to Sekaran and Bougie (2013), the population refers to the entire group of people, events or things of interest that the researcher wishes to investigate. The sample of this study consisted of 100 respondents randomly selected from Malay students around Kuala Lumpur. The sample selected were willing to participate in the research.

\subsection{Questionnaires}

The questionnaire consists of two parts: Part A and Part B. In Part A, the questions asked were regarding student's background such as age, gender, type of institutions and education level. Part B contains items on $H A L A L$, brand, safety, price and quality.

\subsection{Findings and Discussion}

Detailed discussion on the findings is summarised below.

\subsection{Students' Profile}

Most of the students are females, aged between 21 and 23 years old and were pursuing bachelor's degrees in private universities as shown in Table 1 below.

\begin{tabular}{|c|c|c|c|c|c|}
\hline Items & Frequency & $\%$ & Items & Frequency & $\%$ \\
\hline Gender & & & Institution & & \\
\hline Male & 19 & 19.0 & IPTS & 89 & 89.0 \\
\hline Female & 81 & 81.0 & IPTA & 11 & 11.0 \\
\hline Total & 100 & 100.0 & Total & 100 & 100.0 \\
\hline Items & Frequency & $\%$ & Items & Frequency & $\%$ \\
\hline Age & & & Education & & \\
\hline $18-20$ years old & 8 & 8.0 & Diploma/Certificate & 8 & 8.0 \\
\hline 21-23 years old & 71 & 71.0 & Bachelor & 92 & 92.0 \\
\hline 24 and above & 21 & 21.0 & Master/PHD & 0 & 0 \\
\hline Total & 100 & 100.0 & Total & 100 & 100.0 \\
\hline
\end{tabular}




\subsection{Reliability Analysis}

The Cronbach Alpha value for each feature of skincare products is high, that is above 0.700 , and only one (1) item if deleted for the Halal dimension would increase the reliability of the dimension as shown in Table 2.

Table 2: Reliability Analysis

\begin{tabular}{ccccc}
\hline Factors & $\begin{array}{c}\text { Number of } \\
\text { Items }\end{array}$ & $\begin{array}{c}\text { Number of Items } \\
\text { Deleted }\end{array}$ & $\begin{array}{c}\text { Total Number of } \\
\text { Items }\end{array}$ & Cronbach's Alpha \\
\hline Halal & 4 & 1 & 3 & 0.735 \\
Brand & 4 & 0 & 4 & 0.873 \\
Safety & 5 & 0 & 5 & 0.884 \\
Price & 5 & 0 & 5 & 0.842 \\
Quality & 4 & 0 & 4 & 0.774 \\
\hline
\end{tabular}

\subsection{Findings and Hypothesis Test}

All hypotheses are significant and accepted as shown in Tables 3 and 4.

\subsubsection{Hypothesis1: Malay students prefer HALAL skin care products.}

Hypothesis 1 is accepted $(p=0.000)$ and the mean $=4.4167)$. Most of the students agreed that they preferred to purchase skin care products that were non-animal based (mean $=4.4600$ ), free from alcohol (mean $=4.4300)$ and JAKIM certified products (mean $=4.3600)$. As for halal, all the three items which nonalcohol were based, non-animal based, and JAKIM certified skincare products had influenced Malays students' decision in purchasing skincare products. It shows that most Malay students preferred HALAL skincare products.

\subsubsection{Hypothesis 2: Malay students prefer branded skincare products.}

Hypothesis 2 is accepted $(p=0.000)$ and the mean $=4.0200$. Most of the students agreed that they preferred to purchase branded skincare products because they can be trusted (mean=4.1300), effective $(m e a n=4.0200)$, trusted brand (mean $=4.0100)$, and international brand (mean $=3.9200)$. Thus, brand is important for Malay students in making decisions on purchasing skincare products. Decisions on brand includes brand image that is well-known for effectiveness, trusted brand or brand reputation and international brands which are perceived as of superior quality as compared to local brands.

\subsubsection{Hypothesis 3: Malay students prefer safe skin care products.}

Hypothesis 3 is accepted $(p=0.000)$ and the mean $=4.3600$. Most of the students agreed that they purchased safe skincare products that contain safe ingredients (mean $=4.4300)$, have no side effects on skin (mean $=4.400)$, skincare products that are suitable for their skin (mean $=4.4100)$, certified by KKM or Ministry of Health, (mean $=4.3900)$, and have identified chemical ingredients in the skincare products $($ mean $=4.1700)$. Hence, most Malay students are concerned about product safety that include safe ingredients, no side effects, product suitability, certification from Ministry of Health, and were aware of chemical ingredients when making decisions prior to purchase.

\subsubsection{Hypothesis 4: Malay students prefer expensive price skin care products.}

Hypothesis 4 is accepted $(p=0.000$; mean $=3.9340)$. Most of the respondents agreed that they purchased skin care products although they were expensive (mean $=4.0600)$, purchased HALAL skincare products although expensive (mean $=4.0300)$, purchased reputable skincare products although expensive $($ mean $=3.9900)$, willing to spend more for healthy skin (mean $=3.9400)$, and willing to purchase expensive skincare products as they are more effective (mean $=3.6500)$. In short, price has no impact on students' choice of skincare products. Most of the Malay students were willing to pay more for Halal, product safety, brand reputation, product effectiveness, and skin health.

\subsubsection{Hypothesis 5: Malay students prefer high quality skin care products.}

Hypothesis 5 is accepted $(p=0.000$; mean $=3.9075)$. Most of the students agreed that they purchased high quality skincare products (mean $=4.1300$ ), reputable brands that are known for high quality (mean $=3.9000)$, international brands that are known for high quality (mean $=3.8800$ ), and quality skincare products that are highly recommended in the media (mean $=3.7200$ ). This indicates that most Malay students preferred to purchase high quality skincare products, although they were expensive. 
Table 3: Hypothesis Test - One-Sample T-test One Sample Statistics

\begin{tabular}{|c|c|c|c|c|c|c|}
\hline Factor & \multicolumn{2}{|c|}{$\mathbf{N}$} & Mean & \multicolumn{2}{|c|}{ Std. Deviation } & Std. Error Mean \\
\hline HALAL & \multicolumn{2}{|c|}{100} & 4.4167 & \multicolumn{2}{|c|}{0.66393} & 0.06639 \\
\hline BRAND & \multicolumn{2}{|c|}{100} & 4.0200 & \multicolumn{2}{|c|}{0.79509} & 0.07951 \\
\hline SAFETY & \multicolumn{2}{|c|}{100} & 4.3600 & \multicolumn{2}{|c|}{0.70381} & 0.07038 \\
\hline PRICE & \multicolumn{2}{|c|}{100} & 3.9340 & \multicolumn{2}{|c|}{0.77541} & 0.07754 \\
\hline QUALITY & \multicolumn{2}{|c|}{100} & 3.9075 & \multicolumn{2}{|c|}{0.71036} & 0.07104 \\
\hline \multicolumn{7}{|c|}{ One Sample Test } \\
\hline & \multicolumn{6}{|c|}{ Test Value $=3$} \\
\hline & \multirow[t]{2}{*}{$\mathrm{t}$} & \multirow[t]{2}{*}{$\mathrm{df}$} & \multirow[t]{2}{*}{ Sig. (2-tailed) } & \multirow[t]{2}{*}{$\begin{array}{c}\text { Mean } \\
\text { Difference }\end{array}$} & \multicolumn{2}{|c|}{$\begin{array}{c}95 \% \text { confidence interval of } \\
\text { the difference }\end{array}$} \\
\hline & & & & & Lower & Upper \\
\hline HALAL & 21.338 & 99 & 0.000 & 1.41667 & 1.2849 & 1.5484 \\
\hline BRAND & 12.829 & 99 & 0.000 & 1.02000 & 0.8622 & 1.1778 \\
\hline SAFETY & 19.323 & 99 & 0.000 & 1.36000 & 1.2203 & 1.4997 \\
\hline PRICE & 12.045 & 99 & 0.000 & 0.93400 & 0.7801 & 1.0879 \\
\hline QUALITY & 12.775 & 99 & 0.000 & 0.90750 & 0.7665 & 1.0484 \\
\hline
\end{tabular}

Table 4: Hypothesis for purchase decision of skin care products

\begin{tabular}{lccccc}
\hline \multicolumn{1}{c}{ Hypothesis } & $\mathrm{N}$ & Mean & Std. Dev & Sig. (2-tailed) & Accept/Reject \\
\hline $\begin{array}{l}\text { H1: Malay students prefer HALAL } \\
\text { skincare products. }\end{array}$ & 100 & 4.4167 & 0.66393 & 0.000 & Accept \\
\hline $\begin{array}{l}\text { H2: Malay students prefer branded } \\
\text { skincare products. }\end{array}$ & 100 & 4.0200 & 0.79509 & 0.000 & Accept \\
\hline $\begin{array}{l}\text { H3: Malay students prefer safe skin } \\
\text { care products. }\end{array}$ & 100 & 4.3600 & 0.70381 & 0.000 & Accept \\
\hline $\begin{array}{l}\text { H4: Malay students prefer expensive } \\
\text { price skin care products. }\end{array}$ & 100 & 3.9340 & 0.77541 & 0.000 & Accept \\
\hline $\begin{array}{l}\text { H5: Malay students prefer high } \\
\text { quality skincare products. }\end{array}$ & 100 & 3.9075 & 0.71036 & 0.000 & Accept \\
\hline
\end{tabular}

\subsection{Recommendations}

\subsection{Manufacturers and Retailers}

Most of the Malay students were willing to purchase skincare products with features such as product safety and high quality. This indicates that branding can have an impact on students' choice of products to purchase. As a result, this study suggests that retailers develop effective marketing strategies that focus on product safety and product effectiveness of Halal products to provide satisfaction to potential consumers. It was also identified that most Malay students were concerned about facial skincare products, thus it is recommended that manufacturers provide information on Halal ingredients to promote their products. Other critical information on skincare products should be included such as being non-animal based (except for aquatic and land), non-alcohol, product benefits, and Halal logo to indicate halal status. This information should be highlighted in the advertisements and product labels. In conclusion, these efforts can bring benefits to the manufacturer and indirectly increase sales as consumers gain their trust in their skincare products.

\subsection{Conclusion}

The results have shown that the five independent variables investigated in the study namely, Halal status, safety, branding, pricing and quality of skincare products have a significant relationship with the decision to purchase skincare products. Perceived value plays a vital role in consumer decisionmaking (Thomas \& Alex, 2011). Therefore, if manufacturers can understand consumers' perceptions of the value of skincare products in advance, this would will help them to modify their products or improve their marketing strategies to increase sales (Kordnaeij, Askaripoor, \& Bakhshizadeh, 2013). The findings may provide manufacturers with a direction to understand consumers' opinions and perceptions of skin care products, thus, suggesting a future viable marketing strategy to be implemented to promote consumers' purchase decision and further leading to boost in sales and increased profit margins. 
Acknowledgement: Special appreciation goes to Nurfadzira Md. Ridzwan, Nurul Farhana Zolkeflei, Nik Amilin Aimi Nik Adnan, Nabilah Arfah Mohd. Yunus, and Nur Amirah Khalid for data collection.

\section{References}

Ali, S., Halim, F., and Ahmad, N. (2016). Beauty Premium and Halal Cosmetics Industry. Journal of Marketing Management and Consumer Behavior, 1(4), pp.52-63.

Alfred, O. (2013). Influences of price and quality on consumer purchase of mobile phone in the Kumasi Metropolis in Ghana a comparative study. European Journal of Business and Management, 5 (1), pp. 179-198.

Amasa, W., Santiago, D., Mekonen, S., and Ambelu, A. (2012). Are cosmetics used in developing countries safe? Use and dermal irritation of body care products in Jimma Town, Southwestern Ethiopia. Journal of Toxicology, pp. $1-8$.

Ayenimo, J.G., Yusuf, A.M., Adekunle, A.S., and Makinde, O.W. (2010). Heavy metal exposure from personal care Caspion products. Bull Environ Contam Toxicol, 84, pp. 8 - 14.

Foster, L., Haltiwanger, J., and Syverson, C. (2016). The slow growth of new plants: Learning about demand? Economica, 83(329), pp. 91-129.

Din al-Hafiz, A. H. (2008). Surah Al-Maidah verse 87-88. In Al-Quran dan Terjemahanya (p. 122). Kuala Lumpur, Malaysia: Dar El-Fajr Publisher.

Hashim, A. J. C. M., and Musa, R. (2014). Factors influencing attitude towards halal cosmetic among young adult Urban Muslim women: A focus group analysis. INCOMAR 2013. Procedia-Social BehavIoral Sciences, 130, pp. 129-34.

Hunter, M. (2012). The emerging of Halal cosmetics and personal care. Diplomatic Aspects. (Retrieved: October 13, 2017; www.aspectediplomatico.ro).

Hassali M.A., Al-Tamimi, S.K., Dawood, O.T., Verma, A.K., and Saleem, F. (2015). Malaysian Cosmetic Market: Current and Future Prospects. Pharmaceut Reg Affairs, 4(4), pp. 155 - 157.

Khan, A.F., and Khan, M.F. (2013). A Study on the Awareness of Product Ingredients among Women Skincare Users in State of Madhya Pradesh. IOSR Journal of Business and Management, 14(4), pp. 65-72.

Khan, S., and Noor, F. (2012). Factors affecting buying behavior of females for purchase of cosmetics. International Review on Business and Social Sciences, 1(9), pp. 68-76.

Kharim, H.S. (2011). The influence of brand loyalty on cosmetics buying behaviour of UAE female consumers. International Journal of Marketing Studies, 3(2), pp. 123-133.

Khattak, H. (2009). Halal certified cosmetics and personal care products-where purity comes first. Halal Digest, 1, pp.1-3.

Kaur, M., and Mutty, B. (2016). The Commodification of Islam? A Critical Discourse Analysis of Halal Cosmetics Brands. KEMANUSIAAN: The Asian Journal of Humanities, 23.

Kordnaeij, A., Askaripoor, H., and Bakhshizadeh, A. (2013). Studying affecting factors on customers' attitude toward products with halal brand (case study: Kuala Lumpur Malaysia). International Research Journal of Applied and Basic Sciences, 4(10), pp. 3138-3145.

Kotler, P., and Keller, K.L, (2009). Marketing Management. 13 th edition, New Jersey: Pearson Education Inc.

Man, Y. B. C, Bojei, J., Abdullah, A. N., and Latif, M. A. (2007). Halal Food. In Fatimah Arshad, Nik Mustafa Raja Abdullah, Kaur B., and Abdullah, A. M. (Eds.), 50 Years of Malaysian Agriculture: Transformational Issues Challenges and Direction (p. 195-266). Serdang, Malaysia: Penerbit Universiti Putra Malaysia.

Mansor, N., Ali, D. E. B. M., and Yaacob, M. R. (2010). Cosmetic usage in Malaysia: understanding of the major determinants affecting the users. International Journal of Business and Social Science, 1(3), pp. 273-281.

Musa, R. (2014). Factors influencing attitude towards halal cosmetic among young adult Urban Muslim women: A focus group analysis. Procedia-Social and Behavioral Sciences, 130, pp. 129-134.

New Straits Times. (2017). Health Ministry bans seven cosmetics products containing poison. (May 26).

From https://www.nst.com.my/news/nation/2017/05/242987/health-ministry-bans-seven-cosmetics-productscontaining-poison

Ralston, R. W. (2003). The effects of customer service, branding, and price on the perceived value of local telephone service. Journal of Business Research, 56(3), pp. 201-213.

Thomas, S., and Alex, D. (2011). Impact of Product Quality, Service Quality and Contextual Experience on Customer Perceived Value and Future Buying Intentions. European Journal of Business and Management, 3(3), pp. 307315.

Sekaran, U., and Bougie, R. (2013). Research Methods for Business. $6^{\text {th }}$ edition, New York: John Wiley and Sons. 